\title{
Space Debris Mitigation and the Brazilian Foreign Space Policy
}

\section{Article History}

Received: 30 August, 2021

Revised: 12 October, 2021

Accepted: 18 October, 2021

Published: 27 October, 2021

Copyright $\odot 2021$ Noble Academic Publisher \& Author

\section{Fernanda Diógenes Gomes Vieira}

Master's Student of the Postgraduate Program in Aerospace Science, UNIFA.

Raphael de Almeida Leitão

Master's Student of the Postgraduate Program in Aerospace Science, UNIFA.

Dr. Afonso Farias de Sousa Júnior

Teacher in Program in Aerospace Science at Air Force University, PPGCA-UNIFA.

\section{Dr. Murillo de Oliveira Dias*}

Coordinator of DBA Programs at Fundação Getulio Vargas, Brazil.

\begin{abstract}
This article addressed the importance of adopting space debris mitigation strategies based on Brazilian government policy. Key findings pointed out that space debris is an issue with social, environmental, and economic impacts on global scale. Additionally, the Brazilian Government guarantees national security and establishes its aerospace sovereignty. Findings pointed out the relevance of space debris mitigation as a crucial government policy to address the creation of general Brazilian space law, as well as the opportunity for investments in the space sector as a whole in order to provide the training of civilians and military in the development of equipment to remedy the problem. Discussion on case implications and future research recommendations compile the present work.
\end{abstract}

Keywords: Space Debris, Brazilian Space Policy, Impacts, Mitigation.

\section{Introduction}

The present work aims at identifying the socio-environmental and economic impacts arising from space debris, as well as analyzing the importance of adopting mitigating measures based on the Brazilian space foreign policy in order to propose viable recommendations to remedy this problem. Once space debris might enter Earth's atmosphere and affect air navigation, as well as affecting both human-crewed and crewless space vehicles, national policies are designed by governments from Nations directly interested in space navigation, as in the Brazilian single case study, with the national policy on space debris as the unit of analysis [1].

The subject under review has attracted the attention of recent research on the field [2-11](Dias, M., Lopes, R., Teles, 2020; Dias, M., Lopes, R., 2020; Dias, M., 2020, 2020b; Cruz, B.S.; Dias, M., 2020; Dias, M., 2019; Dias, M.; Lopes, R., 2019; Dias, M.; Pessanha, M., 2019; Dias, M., 2019; 2019b)

After WWII, two adversaries' superpowers, the United States (U.S.) and the former Soviet Union (USSR), engaged in an ultimate race to achieve superior spaceflight capability, known as the Space Race.

These two nations emerged from WWII as winners and competitors regarding the ballistic missile-based nuclear arms race. Along with the Space Race, artificial satellites, space probes, robotic devices, space aircrafts rocket-propelled, rocket engines, amongst others, populate the outer space, traveling at approximately $25,300 \mathrm{~km} / \mathrm{h}$ in low Earth orbit. Such debris could eventually collide with space crafts or even artificial satellites, with potential danger to human-crewed space vehicles or crewed spacecraft [12].

To date, approximately thirty thousand orbital or space debris, both (i) natural (such as meteoroid debris) and (ii) artificial debris (human-made satellites, robotic probes, for instance), known as "space junk," are tracked by the North American Space Agency (NASA). Figure 1 illustrates the space debris, as follows: 
Fig 1: - Space debris. Source: NASA (2021). Reprinted under permission

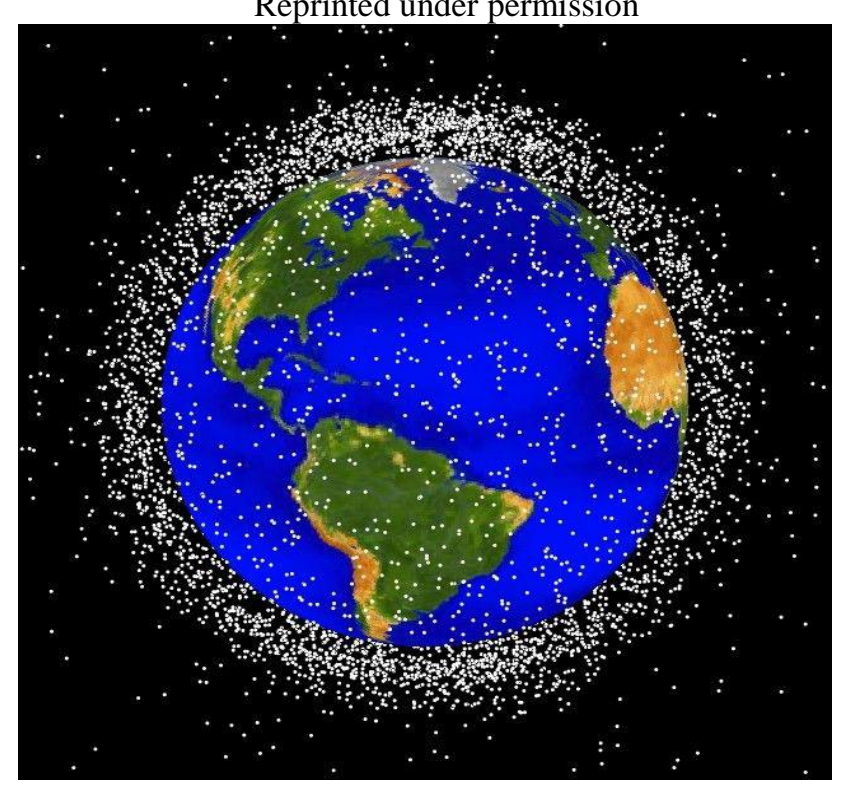

Therefore, space activities have become constant, and dependence on the products and services resulting from them has grown stronger over time. Thus, the number of space debris around the Earth has grown and may generate irreversible social, environmental, and economic risks. For this reason, the present work aims to identify the socio-environmental and economic impacts arising from space debris and analyze the importance of adopting mitigating measures based on the Brazilian space foreign policy to propose viable recommendations to remedy this problem.

In the following sections, we present the research design, the literature review on the topic. Finally, analysis of the results and discussion complete the present article.

\section{Methods and Research Limitations}

We adopted a qualitative research design based on inductive rationale and an interpretive approach through a comprehensive literature review. Concerning the objectives, it proposes identifying, describing, and relating the object of study. As to the approach to the problem, it is done employing qualitative and quantitative research, since there is the presence of qualifying elements and quantifying data and in order to understand the object, archival research from the Space Agencies, from the Brazilian Government archives, National Defense Policy, National Defense Strategy, and Commander's Directive. This article is limited, however, to the Brazilian space debris policy. Other countries or policies should be investigated separately.

Nevertheless, the Brazilian Government abides by the laws dealing with space debris are the 1972 London Convention on International Liability for Damage Caused by Space Objects, known as the Liability Convention, the agreement was reached in the General Assembly in 1971, according to the resolution 2777, XXVI, which Convention entered into force in September 1972. The article is also limited to Article 7 of the Outer Space Treaty, from 1967, both adopted by the [13]. Finally, this article is limited to the Decree 71.981 from 22 March 1973, reaffirming the full content of the Convention on International Liability for Damage Caused by Space Objects.

\section{Background}

Studies on strategy, space, and environment have strong relevance in the geostrategic scenario. Over the past decades, classical and contemporary theorists have evidenced efforts to reveal essential nuances in the treatment of fundamental issues for society, as is the case of Space Debris. In the course of this article, Beaufre [14], Gray [15], Moreno [16], Mourão [17], Baptista [18], Vaz Ferreira [19], Garcia [20], ESA. [21] and Brazil [22] were addressed.

The 1960s are considered the Space Age due to the origin of space exploration activities by the then superpowers United States of America (USA) and the Union of Soviet Socialist Republics (USSR), with Sputnik 1 in 1957. From this, the space race resulted in a significant increase in space debris over the years, and, currently, the space environment is polluted, especially in low Earth orbit 
and geostationary orbit, where there are about $90 \%$ of satellites concentrated brought by Vaz Ferreira [19].

Space debris, also called artificial space junk, is manufactured objects. Although they remain in orbit around the Earth, they no longer perform any useful function [16]. Instead, these objects are residues of spacecraft, satellites, and rockets, which, after their functions are accomplished, are left to wander in space, which can cause serious accidents both in orbit and on land [17].

In this perspective, the European Space Agency (ESA) discloses that about 29.180 space debris are being monitored and cataloged by its surveillance network, as well as it is estimated that fragmentation events of these objects have occurred more than 570 times and that the number of space debris over $10 \mathrm{~cm}$ is 34,000 , between $1 \mathrm{~cm}$ and $10 \mathrm{~cm}$ is 900,000 and over $1 \mathrm{~mm}$ to $1 \mathrm{~cm}$ is 128 million [21].

The National Aeronautics and Space Administration (NASA) says more than 27,000 orbital fragments are tracked and approximately 23,000 debris larger than a softball, half a million pieces up to 0.4 inches or 1 centimeter 100 million pieces of debris-about 0.04 inches (or one millimeter). In addition, there are even smaller fragments about 0.000039 inches in diameter [20].

Finally, we analyzed how Brazil should position itself concerning the disposal of space debris according to its foreign space policy.

\section{The Convention on International Liability for Damage Caused by Space Objects}

The Liability Convention agreement was reached in the General Assembly in 1971, through U.N. Resolution 2,777, chapter XXVI, which entered into force in 1972, and the Outer Space Treaty from 1967. The Brazilian Government is one of the Convention's signatory Nations since 1973, one year after the Convention entered into force, through Decree 71.981/73 [23].

\section{The Brazilian Space Debris Policy}

Brazilian Federal Government issued the Federal Decree 71.981, on 22 March 1973, approved by the Legislative Decree No. 77, from 1 December 1972, the Convention on International Liability for Damage Caused by Space Objects concluded in London. In the same year, in Washington and Moscow, three months later, on 29 March 1972. Therefore, the Brazilian Federal Government reaffirmed international cooperation's importance for the peaceful exploration and use of outer space [13].

The Brazilian space foreign policy is constituted by international principles related to outer space exploration, such as the use of space for the benefit and interest of humanity; the right to freedom of exploration of the space environment in a similar way to all states; the guarantee of international peace and security; and compliance with International Law and the United Nations Charter [24]. Moreover, the principles of international cooperation and mutual assistance are also essential for interpreting the Treaty on Principles Regulating the Activities of States in the Exploration and Use of Outer Cosmic Space, including the Moon and other celestial bodies, in environmental matters, of which Brazil is a signatory. With this, the National Defense Strategy (END) brings the space sector as of strategic national interest, so that it is up to the Brazilian Air Force (FAB) and the Brazilian Space Agency (AEB) the defense and support, respectively, aerospace on behalf of society.

Thus, the Strategic Program for Space Systems (PESE) was created through Normative No. 41/M.D., of 30 July 2018, to establish the "basic guidelines and necessary guidelines for the long-term implementation of defense Space Systems projects.

Such products have dual-use (military and civilian), respecting the peculiarities of each system" [25]. Thus, the FAB promotes space remote sensing to the Armed Forces and government agencies to benefit military activities, national security, environmental control agencies, and natural disasters, as is the Geostationary Defense and Strategic Communications Satellite (SGDC) [18]. Brazil is considered as a launching space debris state, responsible for its registration. According to articles 1 and 4 of the 1975 Convention of Registration of Space Objects, it is possible to examine and monitor the socioenvironmental impacts that may occur. The conservation of the space environment is a duty of the State, as it is responsible for ensuring national security and the individual's right to the environment based on the 1988 Federal Constitution. Aerospace sovereignty is of utmost importance for national defense because, besides giving an international projection of power and control of space objects emissions, it enables the management of space debris not to cause severe damage to life in society. 
Therefore, the control of these orbits, especially the geostationary one, by the State is essential for the effectiveness of this sovereignty, but for this to occur, it is necessary to mitigate space debris.

According to Gray [15] analysis, Clausewitz understands that "strategy is the use of tacit and explicit threats, as well as actual battles and campaigns, to advance political purposes." Thus, strategy is not necessarily focused on military employment but can be elaborated by other instruments of power that achieve the intended ends of the State.

A space strategy focused on the environmental issue corroborates the above understanding so that the FAB and AEB could protect the space environment, being an alternative instrument of power to obtain the control of orbits and project Brazil in the international arena.

Moreover, according to Beaufre [14], this strategy has a defensive objective, considering that territorial integrity and national heritage are fundamental, since Brazil is the country with the most considerable territorial extension in South America and the fifth-largest in the world, being susceptible to accidents resulting from the fall of space debris on its soil.

\section{Discussion}

The space debris pollutes the space, as well as, in case of their fall, the toxic elements in contact with soil and water can cause irreparable damage. As far as risks to society are concerned, space debris, when it comes into contact with the Earth's surface, can cause casualties or damage to property. In this sense, a fragment of a Soviet rocket entered the atmosphere in the direction of Rio de Janeiro on 11 March 1978, at 1:20 a.m. Hundreds saw this of curious people due to the brightness of the light. Hundreds saw this of curious people due to the luminosity emanated by the space object. However, if its entry had occurred minutes earlier, the space debris would have collided in an urban area of Rio de Janeiro and not in the Atlantic Ocean [17].

About economic aspects, space debris can hit and damage satellites in the following strategic areas: meteorological, communication, earth observation, navigation, and space monitoring. These satellites are launched to remain in low and geostationary orbits, which are currently saturated with such objects. Therefore, in an accident, the consequences on Earth are enormous because the services and products that depend on this technology, if disrupted, might suffer untold damage.

Taking the lead in Latin America, standing out in the geopolitical scenario, Brazil has stood out as a state that launches objects into orbit, examining and monitoring the social and environmental impacts that may occur. Since the preservation of the space environment is the State's duty, as it is responsible for guaranteeing national security and the individual's right to the environment, based on the Federal Constitution of 1988.

With aerospace sovereignty highly relevant to maintaining national defense, it is up to the country to grant international projection of power and control of space object emissions to manage space debris so that they do not cause severe damage to society.

It is up to Brazil to control these orbits, mainly geostationary, as well as a spatial strategy focused on the space environment, even more, if we consider that the country has the most significant territorial extension in South America and is the fifth-largest in the world, susceptible, therefore, to accidents resulting from the fall of space debris on its soil.

Thus, it is a matter that deserves the full attention of countries that intend to obtain strategic relevance in the space area, such as the case of Brazil, as it affects sovereignty, national heritage, and territorial integrity, an objective expressed in the National Defense Policy and the National Defense Strategy. As explained by Professor Gills on "the art of the dialectics of wills" [26], from the moment something meets these objectives, such as the case of space debris, a Brazilian mitigation plan must be outlined. Finally, it is noteworthy that the information throughout the article gives substantial shelter to the importance of making efforts and serving as a subsidy to encourage the reduction of debris in the space.

\section{Conclusion}

The present study found that the space debris mitigation strategy should be done through a Brazilian general space law [27], based on the Outer Space Treaty, the 1988 Federal Constitution, the mitigation standards of the Interagency Space Debris Coordination Committee (IADC), the guidelines on Space Debris mitigation of the Committee on the Peaceful Uses of Outer Space (COPUOS), National Defense Policy (PND), National Defense Strategy (END), National Space Policy, and National Policy for the Development of Space Activities (PNDAE). Besides infra-constitutional legislation and national and international devices elaborated on the subject. 
Cleaning space initiatives, such as the CleanSpace One, reveals interesting approaches to collecting space debris: (i) electrodynamic rope, consisting of a long cable, which attached to the satellite, drags the garbage to the Earth's surface; (ii) satellite launched with the aerogel, a "superglue" capable of gathering space debris; (iii) foam, a method similar to the aerogel; (iv) lasers to remove debris, for instance.

For future research, an investigation into the impacts of space debris is encouraged for long-term sustainable development in space, as space activities are becoming more frequent and the environment needs to be passable. In addition, single or multiple case studies are encouraged to be investigated in future studies.

\section{References}

[1] R. Yin, "Estudos de Caso. Editora Bookman, Porto Alegre, terceira edição," 2003.

[2] M. Dias, R. Lopes, and A. Teles, "Could Boeing 737 MAX Crashes be Avoided? Factors that Undermined Project Safety," Global Scientific Journals, vol. 8, pp. 187-196, 2020.

[3] M. Dias and R. Lopes, "Case on Leading Commercial Aircraft in the Brazilian Domestic Aviation Market," International Journal of Academic Research in Accounting, Finance and Management Sciences, vol. 10, pp. 165-171, 2020.

[4] M. Dias, "Case on Domestic Air Passenger Transport Market in Brazil," The Journal of Middle East and North Africa Sciences, vol. 6, pp. 5-9, 2020.

[5] M. Dias, "Air Transportation in Brazil: São Paulo Congonhas Airport," Global Scientific Journals, vol. 8, pp. 3244-3252, 2020 b.

[6] B. S. Cruz and M. Dias, "Crashed Boeing 737-MAX: Fatalities or Malpractice?," Global Scientific Journals, vol. 8, pp. 2615-2624, 2020.

[7] M. Dias, "Brasilia International Airport and the Evolution of Civil Aviation in Brazil," East African Scholars Journal of Economics, Business and Management, vol. 2, pp. 734-737, 2019.

[8] M. Dias and R. Lopes, "The Evolution of Civil Aviation in Brazil: Rio de Janeiro International Airport Galeão/Tom Jobim," JResLit Journal of Science and technology, vol. 1, pp. 1-6, 2019.

[9] M. Dias and M. T. Pessanha, "Air Passenger Transportation in Latin America," Global Scientific Journals, vol. 7, pp. 144-156, 2019.

[10] M. Dias, "Santos Dumont Airport: Civil Aviation in Rio de Janeiro, Brazil," Saudi Journal of Engineering and Technology, vol. 4, pp. 418-421, 2019.

[11] M. Dias, "Air Passenger Transportation in Brazil," Global Scientific Journals, vol. 7, pp. 310-317, 2019 b.

[12] NASA., "Space Debris and Human Spacecraft," 2021.

[13] United Nations, "Convention on International Liability for Damage Caused by Space Objects," 2021.

[14] A. Beaufre, "Introdução à Estratégia. Biblioteca do Exército. Rio de Janeiro-RJ," 1998.

[15] C. S. Gray, "Estratégia Moderna. Biblioteca do Exército, Rio de Janeiro," 2016.

[16] M. Moreno, "O Direito Espacial como Norte da Exploração Espacial. Trabalho de Conclusão de Curso. UEL - Universidade Estadual de Londrina, 2008, p. 146," 2008.

[17] R. R. F. Mourão, "Lixo Espacial: a ameaça às naves espaciais. Revista Eco 21, Rio de Janeiro, 52 ed., 2001. Disponível em," 2001.

[18] J. C. Baptista, "Diretriz do Comandante 2021-2022. Brasília, DF: COMAER, 2021," 2021.

[19] L. Vaz Ferreira, "Aula de Estratégia Espacial na Turma do PPGCA/2021 da UNIFA durante a Disciplina de Pensamento Estratégico Militar Contemporâneo I. Universidade da Força Aérea. 2021, 59 dispositivos, color. -353, 2016," 2021.

[20] M. Garcia, "Space debris and human spacecraft. NASA [Site], Estação Espacial, 26 maio 2021. Disponível em," 2021.

[21] ESA., "Space Debris by the numbers. The European Space Agency - ESA [site], Segurança, 09 jul. 2021. Disponível em," 2021.

[22] Brazil, "Ministry of Defense. National Defense Policy and National Defense Strategy.. Brasília, DF: Ministério da Defesa, 2016. Disponível em," 2016.

[23] Brazil, 1973.

[24] Brazil, "Ministry of Defense. White Paper on National Defense 2020. Brasília, DF: Disponível em," 2020.

[25] Brazil, "Ministry of Defense. Portaria Normativa no 41/MD, de 30 de julho de 2018. Aprova o Programa Estratégico de Sistemas Espaciais - MD20-S-01. Diário Oficial da União, Brasília, DF, 2018. Disponível em," 2018. 
[26] L. G. Vilar, "Aula de Introdução à Estratégia na Turma do PPGCA/2021 da UNIFA durante a Disciplina de Pensamento Estratégico Militar Contemporâneo I. Universidade da Força Aérea, jun. 2021. 1 vídeo (52:18 min). Disponível em," 2021.

[27] M. Santos, P. Souza, and I. Grosner, "A necessidade de uma lei geral do espaço no Brasil," Revista Direito da Universidade de Brasília, Brasília, vol. 4, pp. 106-138, 2020. 